\title{
The Proposed Expert Evidence Bill
}

$\mathrm{H}$ ARDLY any defect in the administration of the law has been so much exploited as that connected with expert testimony. It has been for years the theme of bar association meetings, medical societies and other similar bodies, yet nothing has been accomplished, in the way of remedy, from all this discussion. Under the present system of expert testimony, each side calls its own experts who testify in open court subject to cross-examination. The evils of the system are conceded and are many.

I. Method of selection.

I. The parties and their attorneys are seldom in a position to know who are the real experts in a subject. Some presumptuous, plausible charlatan, who advertises himself widely often usurps the place of the expert in the public eye. "The colossal impudence" of these "experts" is a constant source of amazement to those who are eminent in the profession.

2. Many experts are consulted by litigants, but only those are chosen who will testify favorably. The honest expert seldom gets a chance unless the attorney knows in advance that his testimony will be favorable to his client in all respects. The advantage thus given to dishonest witnesses, who will testify according to the necessities of the case is evident.

3. The expert is selected not as other witnesses, because acquainted with the facts of the particular case, but to draw from the facts conclusions which the layman is unable to do. The expert is thus selected by the party to advise him as to correct conclusions, much as the lawyer is selected to explain the law. The lawyer, however, never alters his character of adviser and advocate. If he takes the stand to testify in an endeavor to win a case for a client, he subjects himself to well deserved criticism. ${ }^{1}$ The expert alone combines the incompatible functions of adviser and witness. The situation is anomalous. It is difficult for the most honest expert to avoid the natural bias which comes from espousing one side of a case and studying it thoroughly. Unconsciously the impartial expert becomes a partisan like the lawyer.

1 Canons of Ethics of the American Bar Association, § 19. 
4. The foregoing and subsequent objections are felt so keenly that many competent experts will not appear in court where their appearance necessarily subjects them to the imputation of dishonesty, and where the methods of examination are incompatible with truth and dignity.

II. Examination of the expert.

I. The method of examination by question and answer is well calculated to mislead. The attorney calling the witness asks such questions, and puts them in such form, as will elicit answers favorable to his side. The expert has been allowed to present only a portion of the case. Either the rest of the case is not brought out by cross-examination, in which event the expert appears to have given an opinion favorable to the side on which he was called when on the merits of the whole case his opinion would be different, or if the other facts are brought out by cross-examination, the expert, through no fault of his own, is made to appear to have concealed the truth. The expert should be permitted to draw his conclusions with the explanations and qualifications necessary to accuracy.

2. The technical applications of the rules of evidence, especially those relating to the opinion rule and to the hearsay rule, are serious impediments to the expert presenting the truth as he sees it.

3. The expert may be continually interrupted by objections on direct examination, and he may be badgered and brow-beaten on cross-examination. By the clever tricks of a skillful lawyer an able expert may sometimes be made to appear in a foolish light.

III. Decision of the case.

When the experts disagree the decision must be left to a nonexpert tribunal, the judge or the jury as the case may be. This is but little better than tossing up a coin. The parties have simply put themselves upon the ignorance of the court.

For these unquestioned evils there are, as Judge Melvin once remarked in another connection, remedies "as numerous as prescriptions for the cure of rheumatism and generally about as useful". For the selection of experts it has been suggested that they be chosen by the court, either reserving the right of the parties to call additional witnesses, or denying such right; that the selection of the court be unassisted, or that the selection be made from an official list chosen in some other manner; that the official 
list be either permanent or a special list for each case. In regard to the examination of witnesses, it lias been recommended that the examination be by the court, with or without the right of the parties to cross-examine. It has also been recommended that there be no examination at all, but that the expert testify in the form of a report. In regard to the decision where experts disagree, it has been recommended that a jury of experts be selected, that an expert sit with the judge during the trial and advise him, that the questions on which expert testimony is required be submitted to an expert, as referee, to make a report binding on the judge and jury. Many modifications of these suggestions are possible. It is obvious that some of them are inconsistent with others, and that it would be an impossible feat to draft a bill that would cure all the evils. The admitted evils create an insistent demand for a remedy, but there is also the logical possibility that no remedy exists, or that any proposed remedy brings in its train new evils worse than the diseases which it cures. A proposed measure must therefore pass the following tests:

I. It must cure a certain evil.

2. It must not cause evils more serious than those that are cured.

Let us apply these tests to the proposed bill now pending before the legislature of the state of California, which reads as follows:

An act to amend the Code of Civil Procedure of California by adding thereto a new section to be numbered and known as section I87I, relating to experts, their appointment by the court, or a judge thereof, and providing for their compensation and manner of examination as witnesses.

The people of the State of California do enact as follows:

Section I. A new section is hereby added to the Code of Civil Procedure of California, to be numbered and known as section $\mathrm{r} 87 \mathrm{r}$, and to read as follows:

I871. Whenever it shall be made to appear to any court or judge thereof, either before or during the trial of any action or proceeding, civil or criminal, pending before such court, that expert evidence is, or will be required by the court or any party to such action or proceeding, such court or judge may, on motion of any party, or on motion of such court or judge, appoint one or more experts to investigate and testify at the trial of such action or proceeding relative to the matter or matters as to which such expert evidence is, or will be required, and such court or judge may fix the compensation of 
such expert or experts for such services, if any, as such expert or experts may have rendered, in addition to his or their services as a witness or witnesses, at such amount or amounts as to the court or judge may seem reasonable. In all criminal actions and proceedings such compensation so fixed shall be a charge against the county in which such action or proceeding is pending and shall be paid out of the treasury of such county on order of the court or judge. In all civil actions and proceedings such compensation shall, in the first instance, be apportioned and charged to the several parties in such proportion as the court or judge may determine and may thereafter be taxed and allowed in like manner as other costs. Nothing contained in this section shall be deemed or construed so as to prevent any party to any action or proceeding from producing other expert evidence as to such matter or matters, but where other expert witnesses are called by a party to an action or proceeding they shall be entitled to the ordinary witness fees only and such witness fees shall be taxed and allowed in like manner as other witness fees. Any expert so appointed by the court may be called and examined as a witness by any party to such an action or proceeding or. by the court itself, and, when called and examined by the court, may be cross-examined by the several parties to the action or proceeding in such order as the court may direct. When such witness is called and examined by the court, the several parties shall have the same right to object to the questions asked and the evidence adduced as though such witness were called and examined by an adverse party. The court or judge may, at any time before the trial or during the trial, limit the number of expert witnesses to be called by any party. ${ }^{2}$

The bill does not do away with partisan witnesses. Each side can still call its own experts. The evils connected with such witnesses therefore remain. That the bill is wise, however, in thus allowing the parties to call their own experts, seems beyond serious question. In a personal injury case, for example, no witness can ordinarily contribute so much of fact as the physician who has attended the plaintiff. In determining value for rate fixing and for other purposes, who is so well equipped to explain the matter to the tribunal as the engineer who has constructed the plant, and who has spent years in study of every item on the schedule? It is true that such a witness inay be biased, but the court or jury can take that matter into consideration. Such witnesses are really

2 Senate Bill No. 13, introduced by Senator Jones, Jan. 7, 1915. 
testifying to facts as well as to opinions. Their position is very different from that of the expert who testifies entirely on the basis of a hypothetical case; or as a law-student once expressed it, "Expert testimony is always founded on fictitious facts". The exclusion of experts, who know the most about the subject matter, on the ground of interest is as foolish as the common law disqualification of the parties to the action as witnesses, a disqualification that has been almost entirely abolished in every jurisdiction. No solution of this problem can be considered for a moment that suppresses material testimony. Yet it is against the expert witness who acts as an adviser, that most of the criticism is directed.

The amendment does not purport to remedy the difficulties connected with the examination of witnesses In preserving the right of cross-examination the bill is conservatively wise. It is, of course, from the point of view of the expert, conducive to his professional dignity to be "sedulously shielded and graciously encouraged" by being allowed to pronounce an ex cathedra opinion. Professional dignity, however, must not be conserved at the sacrifice of truth. Experience has shown that even competent experts make mistakes. To remove the check of cross-examination is to take away the most effective instrument ever devised for the discovery of error. The amendment does not purport to touch the decision of matters where the expert testimony is in conflict.

The scope of the amendment being thus limited, it is evident that it falls short of being a panacea for all evils. About all it purports to accomplish is to put those witnesses appointed by the court in a nonpartisan position. There are serious objections, however, to the bill:

I. In criminal cases the compensation is a charge on the county. The danger is serious that some defense like insanity will be set up in every case where there is the slightest opportunity. It does not cost the defendant anything; the county pays the bill. It will be remembered that the immediate effect of the adoption of section $1247^{\circ}$ of the Penal Code, providing for the writing up of all the evidence in criminal appeals at the expense of the county, was that appeals were taken simply to give the reporter a job. By the proposed amendment the county is saddled with liability indefinite and unlimited in amount. In civil cases the effect is even more dangerous. The cost is apportioned in the first place, and finally charged on litigants as other costs. A poor litigant inay easily be ruined by the calling of expensive experts by the other side. 
2. The bill provides that the court or judge may appoint experts. Does this mean that it is compulsory upon the expert to testify? Will it be satisfactory for an engineer, with a high salary and under contract to his employer, to be called upon to make investigations and to testify for such compensation as may be awarded by the court? If testimony is not compulsory, and to make it compulsory would probably be unconstitutional, the expert will necessarily want to know what his compensation will be, before he can agree to investigate a matter and stand ready to testify on the trial, whenever that shall take place, and for as many days as the trial may continue. Under the present system the matter is adjusted by the bargaining of the parties. The court is in no position to make such arrangements. The example of Germany is cited, but it must be remembered that the conditions are very different. The entire educational system of Germany is devised for the purpose of training experts to carry on the public work. In educational as well as other matters there is a quasimilitary organization. The state trains up its experts on every subject, and it is the natural thing, and is understood by everyone, that the government should call upon these experts when it needs them. There is not in Germany what has been termed "that exaltation of incompetency and distrust of competency in special fields which seems to be an unhappy by-produce of democracy".

3. The court is in no better position to choose experts in the medical profession, in the engineering profession, or in any other profession in which expert testimony is required, than are the litigants. It cannot be too strongly emphasized that a general knowledge of a subject does not make an expert. It is probable that the doctors in California competent to testify as expert alienists in a contested matter could be counted on the fingers of the hand. Is it a fact that the judges show any peculiar ability in the selection of their own private physicians?

4. There is grave danger in allowing the judge to select his own experts. He will naturally be inclined more favorably to his own witness. In some fields in which expert testimony is required, such as in rate-fixing regulation, the competent men are few; they have usually been retained either by the utility or by the state. These men are on record with definite views, honestly entertained, on questions not yet finally determined by the Supreme Court. The judge could hardly be expected to know this bias 
and it would be difficult for a party to make an affidavit of prejudice; nevertheless, the decision of that expert could be predicted in advance, by those familiar with his views. Apparently the court may call witnesses at any time of its own motion, with no opportunity by the parties to make objections or to know in advance of the trial the witnesses that may be called. As the court has no special qualifications for determining the competency of experts, there is danger in the artificial weight given to those selected by the court. The foregoing considerations have led the Michigan court to go perhaps too far in declaring the following section of an act unconstitutional : ${ }^{3}$

"Sec. 3. In criminal cases for homicide where the issues involve expert knowledge or opinion the court shail appoint one or more suitable disinterested persons, not exceeding three, to investigate such issues and testify at the trial; and the compensation of such person or persons shall be fixed by the court and paid by the county where indictment was found, and the fact that such witness or witnesses have been so appointed shall be made known to the jury. This provision shall not preclude either prosecution or defense from using other expert witnesses at the trial."

5. The selection of expert witnesses is an undesirable power to put in the hands of judges. Under the present system of choosing judges by two popular elections, primary and general, the judge, to secure his re-election, must have many friends working for him. $\mathrm{He}$ is in much the same position as the expert who is not called unless he will testify favorably. Unless the judge does politics he will not be a judge. No one is a more effective vote getter than the type of physician known as the "political doctor". It need occasion no surprise to see the political doctor selected as an expert in return for election services, especially since the judge has no divining rod to discover the real expert. Lawyers will recall that the power of the court to appoint an attorney for minor heirs involved the judges in much criticism, usually, it is true, undeserved. The probability of such criticism led more than one judge to avoid probate cases until the law was repealed. ${ }^{4}$ Fixing the compensation of executors, administrators and their attorneys caused so much trouble that an arbitrary standard was adopted by the legislature,

3 People v. Dickerson (1910), 164 Mich. 148, 129 N. W. 199. (The opinion is not based entirely on the provision that the court shall make known to the jury who the court witnesses are.)

\& Cal. Code Civ. Proc., \$ 1718, repealed, 1903. 
with a very limited power in the court of modification. ${ }^{5}$ At the present time we see a single inheritance tax appraiser superseding the appraisers appointed by the court for each case. The blemishes in the careers of Lord Macclesfield, Lord Eldon and other eminent judges arose from this power over patronage and fees. ${ }^{6}$ Experience abundantly demonstrates that the less power a judge has to favor his friends by lucrative appointments, the better able he is to perform his judicial duties.

A bill that accomplishes so little and that raises so many diffculties can hardly be considered expedient. It is highly significant that the long continued agitation for reform has resulted in almost no legislation. Does not this indicate that the evils are of a kind that cannot be cured by passing a statute? In the selection of experts no solution can be considered satisfactory that does not provide for the selection by the profession involved. The members of each profession know their own experts but not those of other professions. In these days of specialization the expert in one branch of a subject has no peculiar qualifications in the others. Would it not be possible for the judges, the medical societies and the bar associations to get together and agree that where a case involves medical expert testimony, unless the parties themselves can agree on experts, the judge shall select from a list, made up by the medical association, of those qualified to testify in that particular kind of case? No one is entirely satisfied with the present order of things. The arrangement suggested has operated with success in some places.

"In many of our cities an understanding exists between the bench and the medical profession that certain men known to be distinguished in a special department of practice shall be regarded as eligible experts, and from a list of these a choice can be properly made. This has not been made mandatory by statutory enactment, but it has been found to be a feasible solution of many difficulties and has greatly facilitated the trial of insanity and other cases where special technical knowledge is demanded of the witness."?

All it needs is a willingness in the judges and lawyers to try it, and above all a willingness on the part of experts in the medical

5 Cal. Code Civ. Proc., §§ 1618, 1619.

- Campbell, Lives of the Chancellors, vol. iv, p. 554; vol. vii, p. 677.

7 Andrew Stewart Lobingier, A.B., M.D., Medical Expert Testimony. 
profession to make a sacrifice of time and money to accomplish this improvement. Perhaps in time, if the arrangement works out successfully, it would be possible to compensate the experts adequately for their services. Other professions can work out their problems along similar lines.

In the examination of experts the improvement must come from the lawyers. If the tactics of counsel are obstructing the truth the court must assert its power. The most serious handicap on the court in this connection is the prohibition against the judge commenting on facts.

"But there is general concurrence among those who have studied the subject in the view that if trial judges were given the power to deal with expert evidence effectively in the charge to the jury, and if they were so selected as to put men of proper caliber upon the bench the question would largely solve itself."'8

The rules of evidence put very few obstacles in the way of an expert stating his opinion. Unfortunately a contrary view still prevails among a number of persons in the profession. The pioneer conditions of the West produced an untrained bench and bar. As usual the ignorant lawyer is very proud of his knowledge of technicalities, a knowledge which on investigation usually proves to be of things which are not so. The artificial rules invented by a misguided generation remain to trouble the profession today. ${ }^{2}$ The modern appellate courts are engaged in clearing away this mass of technicalities, but in the trial courts they are too often enforced. It is impossible to examine the foundations of every question of evidence that comes up during a trial. The most scholarly practitioner must accept much of the routine of trial practice without examination. Again, it does not pay to take chances by putting in evidence, the admissibility of which is doubtful. It is surprising, however, how many of the exclusionary rules, assumed in practice, are really opposed to the weight of authority. An example of this is to be found in a very able address delivered at a joint meeting of the San Francisco Medical Society and the

8 Preliminary Report on Efficiency in the Administration of Justice. The National Economic League, 6 Beacon St., Boston, Mass., p. 27.

- See Wigmore on Evidence, $\S 1917$, for the history of the unfortunate American doctrines on the opinion rule. 
San Francisco Bar Association. ${ }^{10}$ The following quotation is from this address:

"For instance, a medical attendant will not be permitted to give an opinion based upon his own personal observation of a patient and the history of the case as related by the patient. What the patient has told him is regarded as hearsay. In dealing with the case privately the physician forms his opinion and acts upon what he discovers objectively and the history of the case. In court, however, while his testimony is receivable as to objective symptoms, he cannot testify as to subjective symptoms nor can he give the history of the case. Therefore, when asked his opmion as an expert he bases it partly on his personal knowledge and partly on the history of the case as given by the witnesses in court, not as given to him privately."

While there is some conflict of authority on the use of declarations of pain to prove that fact, discriminations being made in various jurisdictions between, for example, declarations of present and past pain, and between spontaneous and narrative declarations, it is generally conceded that the physician is entitled to use such declarations as one of the grounds of his expert opinion.

"In the preceding section we alluded to the inadmissibility of a statement of a party that he suffered pain, made long after the injury; but when a physician is called as an expert, his evidence is not thus limited. He may base his opinions upon a statement given by the patient in relation to his condition and sensations, past and present. Thus only can the expert ascertain the condition of the party; and he may, of course, be guided to some extent by the data thus furnished."11

Rightly understood the rules of evidence offer few embarrassments to the complete statement of the case by an expert. In the decision on matters affecting expert testimony, greater difficulty may be experienced. With the consent of the parties, however, it is always possible to appoint expert referees. ${ }^{12}$ For the improvements above suggested little or no change in the law is required.13 The cause of the disease of expert testimony lies in the ignorance of the professions and in their lack of organization. An act like $17,1914$.

10 Address by William M. Cannon, San Francisco Recorder, Oct.

${ }_{11}$ Jones, Commentaries on Evidence, $\$ 349$ a. See also Chamberlayne, The Modern $L a w$ of Evidence, $\$ 2635$ and cases cited, including People v. Shattuck (1895), 109 Cal. 673, 42 Pac. 315; Wigmore on Evidence, $\$ 1720$.

12 Cal. Code Civ. Proc., \$§ 638-645.

13 Wigmore on Evidence, $\S 562$. 
the one proposed cures a symptom, but as so often happens, turns the disease into another and perhaps more dangerous form. It is pathetic to see the efforts that well meaning reformers make to accomplish a reform by an act of the legislature. If it could only be understood that improvement is a slow process requiring men better trained in the profession, with high ethical standards. The professions must be well organized among themselves so as to know who their real leaders are. They must be able by their organizations to exert an influence upon the other professions. A public opinion must be created that will drive from the courts the incompetent and the dishonest.

For procedural difficulties, the inherent powers of the court are sufficient if there is the desire to use them. ${ }^{14}$ The thing most to be avoided is legislation which will restrict the use of expert testimony and confine it to certain forms. The thing required is a flexibility in procedure that will enable the court to select that method which may best suit the particular case; this may be by experts chosen by the parties, by the judge, by the profession, testifying in court, or filing a report; or any other fair procedure may be adopted that will assist a just decision. We must realize that the fault is in ourselves and can be cured only by continuous effort along practical lines of education and a better mutual understanding. Can we not stop this everlasting rush to the legislature to pass bills to inake men competent and honest? ${ }^{15}$

A. M. Kidd.

Berkeley, California.

14 This was recently demonstrated in San Francisco where it was discovered by Presiding Judge Sturtevant that the court possessed the power to make all rules considered desirable for the expedition of business without resort to the legislature. The co-operation of the judges and lawyers is all that is necessary for efficiency in administration.

15 It may be interesting to note in this connection that the American Institute of Criminal Law and Criminology after several years' work by an able committee has recommended only one bill, a bill confined to expert testimony in cases involving mental disease. Journal of the American Institute of Criminal Law and Criminology, vol. v, pp. 643-652. This bill embodies the valuable permission for the experts to consult before the trial. The right of cross-examination is also preserved. It is necessary to test the opinion of experts even where they agree. The case of Doolin v. Omnibus Cable Co. (1899), $125 \mathrm{Cal}$. 141, $57 \mathrm{Pac}$. 774, is still fresh in mind, where the experts on both sides agreed that the plaintiff was suffering from a tumor. Ten days after the trial she gave birth to a child and it was then admitted she had not suffered from a tumor at all. 